\title{
EVALUATION OF REAL ESTATE MARKET VALUE IN UKRAINE USING WEB-SCRAPING
}

\author{
Oleksandr Antonov; Oleksandra Laktionova
}

\author{
Vasyl Stus Donetsk National University, Vinnytsia, Ukraine
}

\begin{abstract}
Summary. Market value is one of the most important kind of information for every type of business - for startups on the planning stage, as well as for already grown business. It allows to make more accurate revenue predictions at financial planning stage and therefore investment decisions. In some cases, identification of market value can be a trivial task, when, for example, we deal with open organized information, but mostly, estimation of this parameter is very complex task that can be time consuming and requires the involvement of experts in various areas. It becomes even more difficult while trying to estimate the value of illiquid assets such as assets on real estate markets. The objective of the paper is the estimation the real estate market value using the approach of extracting and structuring data from web-sources and available data by web scraping based on Python programming language. Web crawler is more advanced software, it is the artificial intelligence that can navigate the web sites, follow the search links and extract data using specific rules. As the data source, ria.ua web site is chosen. The total market value, according to information represented on ria.ua is approximately \$10,9 billion. The evaluation shows the concentration of market mostly in Kiev, except business property, country houses, hotels, land and warehouses. At the same time, Kiev is the leader in the sphere of office complexes, parking places, recreation. The leaders of apartment sales are Kiev and Odesa regions, other regions are significantly behind Kiev and Odesa. On the basis of carried out analysis, we can come to the conclusion that the price is highly correlated with the type of real estate and moderately correlated with region of sale.
\end{abstract}

Key words: market value, real estate market, web-scraping, value of real estate, Big Data.

https://doi.org/10.33108/galicianvisnyk_tntu2020.02.035

Received 21.03.2020

УДК 336.76

\section{ОЦІНЮВАННЯ ВАРТОСТІ РИНКУ НЕРУХОМОСТІ В УКРАЇНI 3 ВИКОРИСТАННЯМ WЕВ-SCRAPING}

\author{
Олександр Антонов; Олександра Лактіонова
}

\section{Донеиький нащіональний університет імені Василя Стуса, Вінниия, Украӥна}

Резюме. Ринкова цінність є одним з важливіших видів інформаџії для кожного виду бізнесу - як для стартапів на етапі планування, так і для вже вирощеного бізнесу. Це дозволяє робити точніші прогнози доходів на етапі фінансового планування, а отже, інвестиційні рішення. У деяких випадках ідентифікація ринкової вартості може бути тривіальним завданням, коли ми маємо справу з відкритою організованою інформацією, але здебільшого, оцінювання цуього параметра є надскладним завданням, яке займає багато часу і вимагає залучення експертів різних сфер. Певні обмеження виникають, якщо оцінюється вартість неліквідних активів, таких, як активи на ринках нерухомості. Розглянуто підхід до оцінювання ринкової вартості ринку нерухомості або його капіталізації за допомогою підходу агрегування та структурування даних із веб-джерел на основі веб-скрейпінгу із використанням мови програмування Python. Webcrawler - ие вдосконалене програмне забезпечення, штучний інтелект, щзо перемішується по веб-сайтах, переходить по посиланнях для пошуку та вилучення даних за допомогою конкретних правил. Загальна ринкова вартість згідно з інформацією, представленою на гіа.иа, приблизно дорівнює на певну дату 10,9 мільярда доларів. Оцінювання показує концентрацію ринку в основному у Києві, за винятком 
комерційної нерухомості, заміських будинків, готелів, земель та складських приміщень. Водночас Київ $\epsilon$ безперечним лідером у сфері офісних комплексів, паркування, рекреачійного відпочинку. Лідерами із продажу квартир є Київ та Одеська область, інші регіони значно відстають від ицих міст. На основі аналізу зроблено висновок, щчо ціна сильно корелює з типом нерухомості та меншою мірою корелює $з$ регіоном продажу.

Ключові слова: ринкова вартість, ринок нерухомості, веб-стрейпінг, иіна нерухомості, Великі дані.

Introduction. Market value is the total value of all products and/or services that are sold on a certain market within a certain period. Estimation of this parameter is one of the most important steps for every startup on a stage of financial planning and it can be very useful for already grown up business because it allows to make more accurate revenue forecasts and output capacity. However, estimation of this value requires a lot of data about specific market, usage of various analytical tools and expert knowledge. Traditional market value estimation approach depends on statistical data, gathered by government and third-party companies, but even if that data exists, we can't be sure about its quality because the data can be not full, which can lead to wrong decisions. There is also difficult to aggregate data using traditional approaches like polls. The internet, on contrary, contains a lot of data that can be very useful for valuation, but the main obstacle is that they can be unstructured and placed on various sources that makes them difficult for analysis. This problem can be bypassed using web scraping techniques.

Web scraping is an automated process of creation the structured representation of data from various web sources using special software - web scraping bots. There are two types of such bots - web crawler and web spider. Web spider is a software designed to extract data from specific source, for example from exact web site using CSS or XPATH selectors. Web crawler is more advanced software, it is an artificial intelligence that can navigate through web sites, follow links to search and extract data using specific rules. The web scraping approach has specific advantages and drawbacks. The advantages are:

- if data exist on web sources - they can be extracted and structured;

- data extraction process, using web scraping, is tremendously faster than manual data collection or traditional data gathering approaches such as polls;

- the data can be updated after a certain time using the same software, which allows to track changes on the market in real time;

- web scraping allows to lower dependencies on statistical data, that are collected by government or third-party companies.

On the other hand, the following disadvantages should be noted:

- writing of web spiders requires a lot of special knowledge and skills in programming field;

- it can be difficult to realize web scraping projects from technical point of view;

- some web resources use different protection systems to prevent data from scraping;

- only available data can be extracted freely, anyone cannot scrape data without data owner's permission under user agreement.

Review of the latest research and literature. The problems of using Intermate data and methodology of Big Data analysis. João Manuel Azevedo Santos used real estate market data scraping and analysis for financial investments [1]. Maciej Beresewicz presented the usage of Internet data sources for real estate market in Poland [2]. EzgiCandas, Seda BagdatliKalkan and Tahsin Yomralioglu tried to determine which parameters can be used as evaluation factors 
for housing prices [3]. Robert Hu and Emil Sjögren searched the best fitted analysis method for prediction the prices for the apartment in Stockholm based on its characteristics [4].

The basis of using Web scraping with Python is described in papers [5-15].

The objective of the paper is to evaluate the Ukrainian real estate market or its capitalization using web scraping technique for collecting data. To achieve this goal, we realized the following tasks:

- the web spider for data extraction is designed. As a source of data, ria.ua web site is chosen, that is one of the biggest platforms of Ukrainian real estate market. The spider should not only collect all necessary data, but also not abuse web source server with too many requests. The spider is written using Python programming language and Scrapy framework;

- collected data should be cleaned and structured before further analysis, for this task Pandas library is used;

- to calculate the value of Ukraine real estate market the collected data must be analyzed, for this purpose Pandas library and data visualization tools - matplotlib, sea born and folium are used.

While their processing we assumed that:

- Only data from ria.ua are used for market value estimation because one unique real estate object can be represented on various web sites, and to remove such duplicated observations special algorithms are to be used.

- The market value is be calculated for a certain date - when data have been collected. To calculate market value for different periods - additional data must be collected.

Data extraction and preprocessing. Project GitHub is posted on repository: https://github.com/rndmBot/Market-value.

The data are collected from Ria.ua - one of the biggest Ukraine advertisement platforms. Web spider is designed using Scrapy - asynchronous web scraping framework for Python programming language. The web spider code can be found on GitHub repository, the spider extracts data from web source and stores it in csv format. Sample of web spider's output is represented in table 1 .

Table 1. Web spider output (5 first observations of 261855)

\begin{tabular}{|l|l|c|c|}
\hline \multicolumn{1}{|c|}{ Parse } & \multicolumn{1}{|c|}{ Parse2 } & Price_usd & Parse3 \\
\hline $\begin{array}{l}\text { /ru/realty-perevireno- } \\
\text { prodaja-kvartira-kiev-so... }\end{array}$ & Solomensky Str. Yerevan 1 room Kiev & $71970 \$$ & $1 \mathrm{room} 57 \mathrm{~m} 2$ \\
\hline $\begin{array}{l}\text { /ru/realty-perevireno- } \\
\text { prodaja-kvartira-kiev-so... }\end{array}$ & SolomenskyMashinobudivnavulitsya 1 room Kiev & $68000 \$$ & $1 \mathrm{room} 68 \mathrm{~m} 2$ \\
\hline $\begin{array}{l}\text { /ru/realty-perevireno- } \\
\text { prodaja-dom-vinnitsa-yak... }\end{array}$ & Yakushintsyst. Bogdan Khmelnitsky 134 m square & $53000 \$$ & 134 м2 hectare \\
\hline $\begin{array}{l}\text { /ru/realty-perevireno- } \\
\text { prodaja-kvartira-vinnits... }\end{array}$ & Sverdlovsk massif st. Matrosa Koshki 1 & $36500 \$$ & $1 \mathrm{room} 36 \mathrm{~m} 2$ \\
\hline $\begin{array}{l}\text { /ru/realty-perevireno- } \\
\text { prodaja-kvartira-vinnits... }\end{array}$ & Strizhavka Alei street 1 room. Vinnitsa & $16582 \$$ & 1 room $40.24 \mathrm{~m} 2$ \\
\hline
\end{tabular}

The raw data contains 261855 observations, the data is not appropriate for analysis in that representation and must be preprocessed. Preprocessing script can be found on Git Hub repository. The preprocessing steps are as follows:

- Null values removal: «price_usd» contains null values, these observations must be dropped, because they do not bring any information. Number of observations after null values removal - 260053.

- «Parse» column preprocessing - the next information can be extracted from this column: 
a) offer type - sell, long term rent (lt_rent), short term rent (st_rent);

b) real estate type - apartments, house, PSN, office, land, part of house, recreational, room, commercial area, services, country house, hotel, industrial, warehouse, business, office complex, garage, parking space;

- extracting city name from «parse2» column;

- «Region» column creation - the region of the city have been extracted using Geopylibrary Nominatim geocoder;

- for convenience of usage, city and region column values have been transliterated from Ukrainian to English using TranslitUA library;

- «parse3» column preprocessing - the next information extracted from this column: number of rooms for apartments, living area, area of a land;

- «price_usd» column preprocessing - the column contains values in Ukrainian hryvnias that must be converted to US dollars and «\$» signs that must be cleaned;

- calculation of price for square meter and 1/100 of hectare.

The preprocessed data represented in table 2.

Table 2. Preprocessed data (first 5 observations of 258984)

\begin{tabular}{|l|l|l|l|l|l|l|l|l|l|l|}
\hline & Price_usd & $\begin{array}{c}\text { Offer_- } \\
\text { type }\end{array}$ & Type & City & Region & Rooms & Area & $\begin{array}{c}\text { Land } \\
-\overline{a r e a}\end{array}$ & $\begin{array}{c}\text { Price_ } \\
\text { sqm }\end{array}$ & $\begin{array}{c}\text { Price_ } \\
\text { hndr }\end{array}$ \\
\hline 0 & 71970.0 & sell & apartments & Kyiv & Kyiv & 1.0 & 57.0 & NaN & 1262.63 & NaN \\
\hline 1 & 68000.0 & sell & apartments & Kyiv & Kyiv & 1.0 & 68.0 & NaN & 1000.00 & NaN \\
\hline 2 & 53000.0 & sell & house & Vinnitsa & Vinnytska & NaN & 134.0 & 7.0 & 395.52 & 7571.43 \\
\hline 3 & 36500.0 & sell & apartments & Vinnitsa & Vinnytska & 1.0 & 36.0 & NaN & 1013.89 & NaN \\
\hline 4 & 16582.0 & sell & apartments & Vinnitsa & Vinnytska & 1.0 & 40.0 & NaN & 414.55 & NaN \\
\hline
\end{tabular}

Data analysis and market value calculation script can be found on GitHub repository: https://github.com/rndmBot/Market-value

The «offer_type» column contains three types of offers - sell, long term rent and short term rent, to calculate Ukraine's real estate market only «sell» offer have been used. After offer selection the data contains 221576 observations. The next step - is the calculation of basic statistics of the Dataset.

Table 3. Basic statistics of the Dataset

\begin{tabular}{|c|c|c|c|c|c|c|c|c|c|}
\hline & Price_usd & Type & City & Region & Rooms & Area & Land_area & $\begin{array}{c}\text { Price_ } \\
\text { sqm }\end{array}$ & Price_hndr \\
\hline Count & 221576 & 221576 & 221576 & 221576 & 159239 & 201114 & 42833 & 201114 & 42831 \\
\hline Unique & nan & 18 & 463 & 25 & nan & nan & nan & nan & nan \\
\hline Top & nan & apartments & Odesa & Odeska & nan & nan & nan & nan & nan \\
\hline Freq & nan & 159245 & 64239 & 68129 & nan & nan & nan & nan & nan \\
\hline Mean & 89064 & NaN & NaN & NaN & 2 & 10557 & 50171 & inf & inf \\
\hline Std & 700380 & NaN & NaN & NaN & 1 & 3161373 & 10376237 & nan & nan \\
\hline Min & 0 & NaN & NaN & NaN & 1 & 0 & 0 & 0 & 0 \\
\hline $25 \%$ & 26000 & NaN & NaN & NaN & 1 & 45 & 6 & 510 & 938 \\
\hline $50 \%$ & 43000 & NaN & NaN & NaN & 2 & 63 & 10 & 725 & 3688 \\
\hline $75 \%$ & 78000 & NaN & NaN & NaN & 3 & 90 & 16 & 1034 & 14833 \\
\hline max & 278000000 & NaN & NaN & NaN & 65 & 1000000000 & 2147480000 & inf & inf \\
\hline
\end{tabular}

The observations according to table 3 are:

- «price usd» column contains zero values that must be dropped. Also, this column contains huge outliers that must be removed before further analysis. 
- «rooms» column, according to maximum value 65, contains huge outliers.

- «area» and «land_area» columns contain huge outliers.

- «price_sqm» and «price_hdnr» columns contain infinite numbers that must be replaced with nan values.

Outliers must be removed before the market value calculation, because they can lead to wrong estimations. Outliers elimination algorithm (source code can be found on GitHub repository) contains:

- splitting dataset according to region and loop through each region;

- for each region splitting data by type of real estate;

- for each type of real estate calculation IQR for each column, that contains numeric values;

- detecting and dropping lower and upper outliers by $1.5 *$ IQR.

After outlier elimination the dataset contains 190214 observations. Figures 1, 2 show the dependence of prices on the type of property and the region of sale. The price is highly correlated with type of real estate and moderately correlated with region of sale.

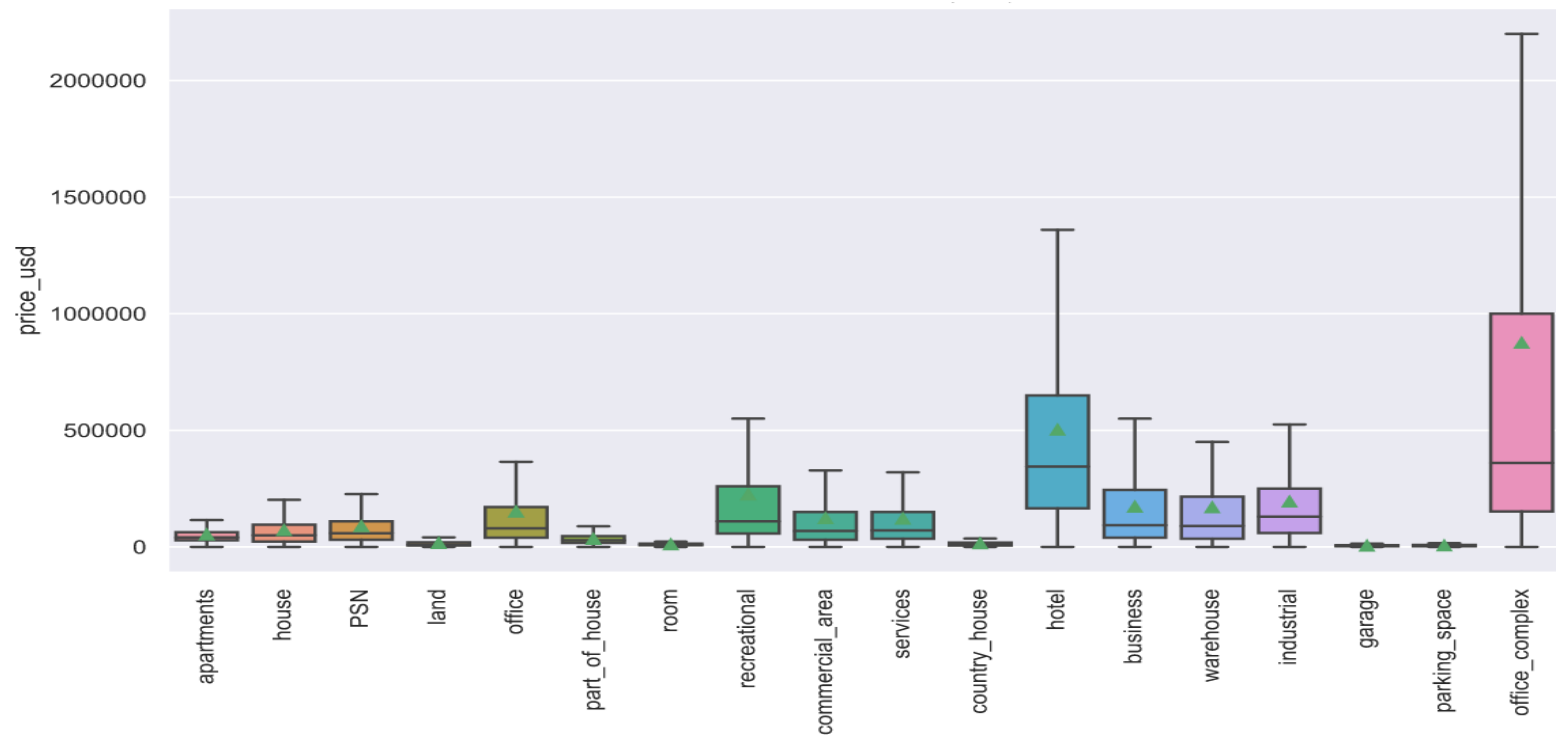

Figure 1. Real estate price according to the type

The next step is the calculation of market value of real estate market in Ukraine or its capitalization. According to the data the next parameters are calculated:

- total Ukraine real estate market value.

- Ukraine real estate market value according to region of sale.

- Ukraine real estate market value according to type of real estate.

- Ukraine's real estate market value according to type and region of sale of real estate.

The total Ukraine's market value is calculated as the sum of all real estate property prices. The total market value, according to information represented on ria.ua is approximately $\$ 10993508874$. Total real estate stock in the world is $\$ 168.5$ trillion with $22 \%$ in North America, 23\% in Europe, 25\% in China and Hong Kong, 19\% Asia Pacific. Although Ukrainian real estate market doesn't include all assets, but is represented only for sales, it is small and constitutes scanty fraction. The share of Ukrainian real estate market in transaction volume on the global market is $1 \%$. 


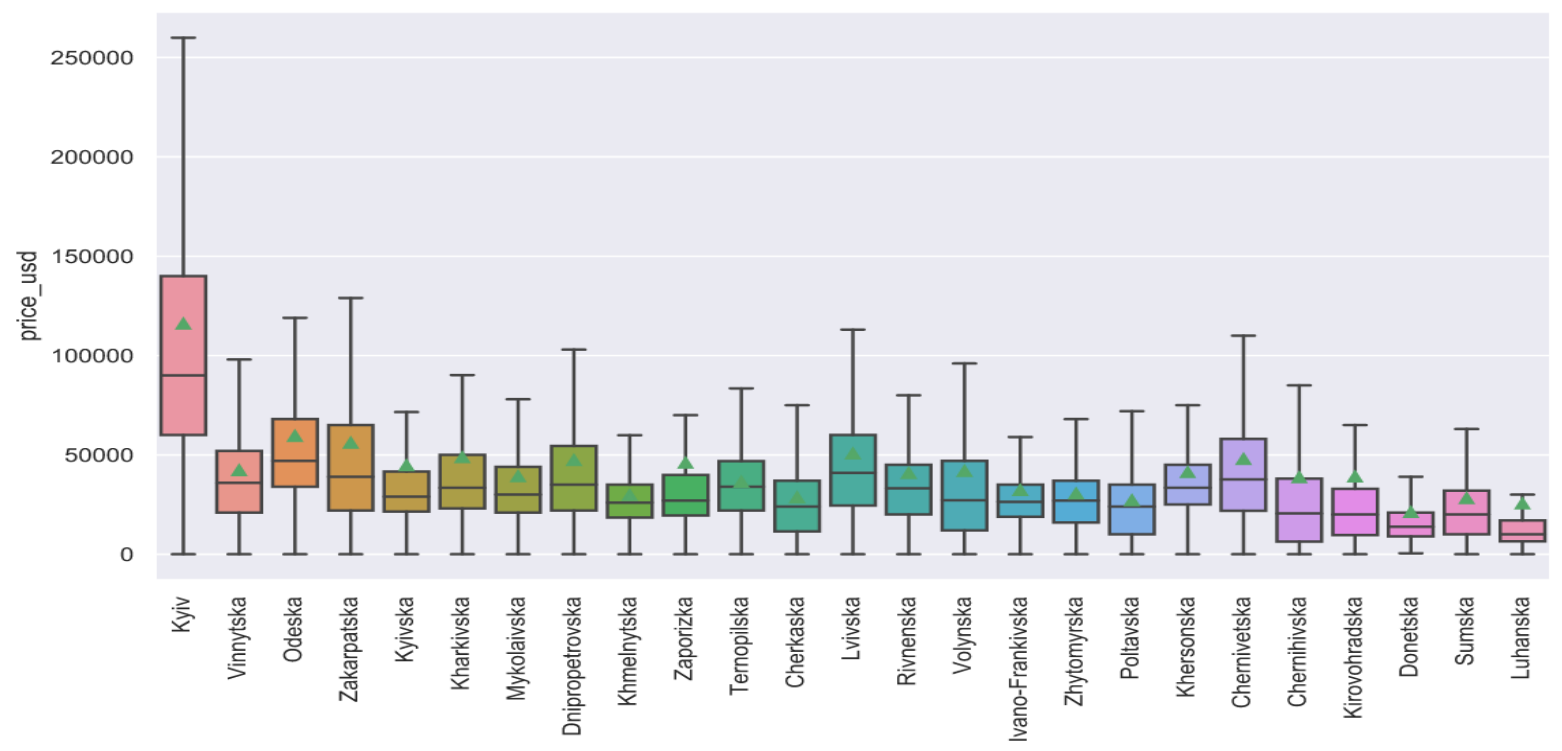

Figure 2. Real estate price according to the region

Market value according to region of sale is represented in Table 4 and in Figure 3.

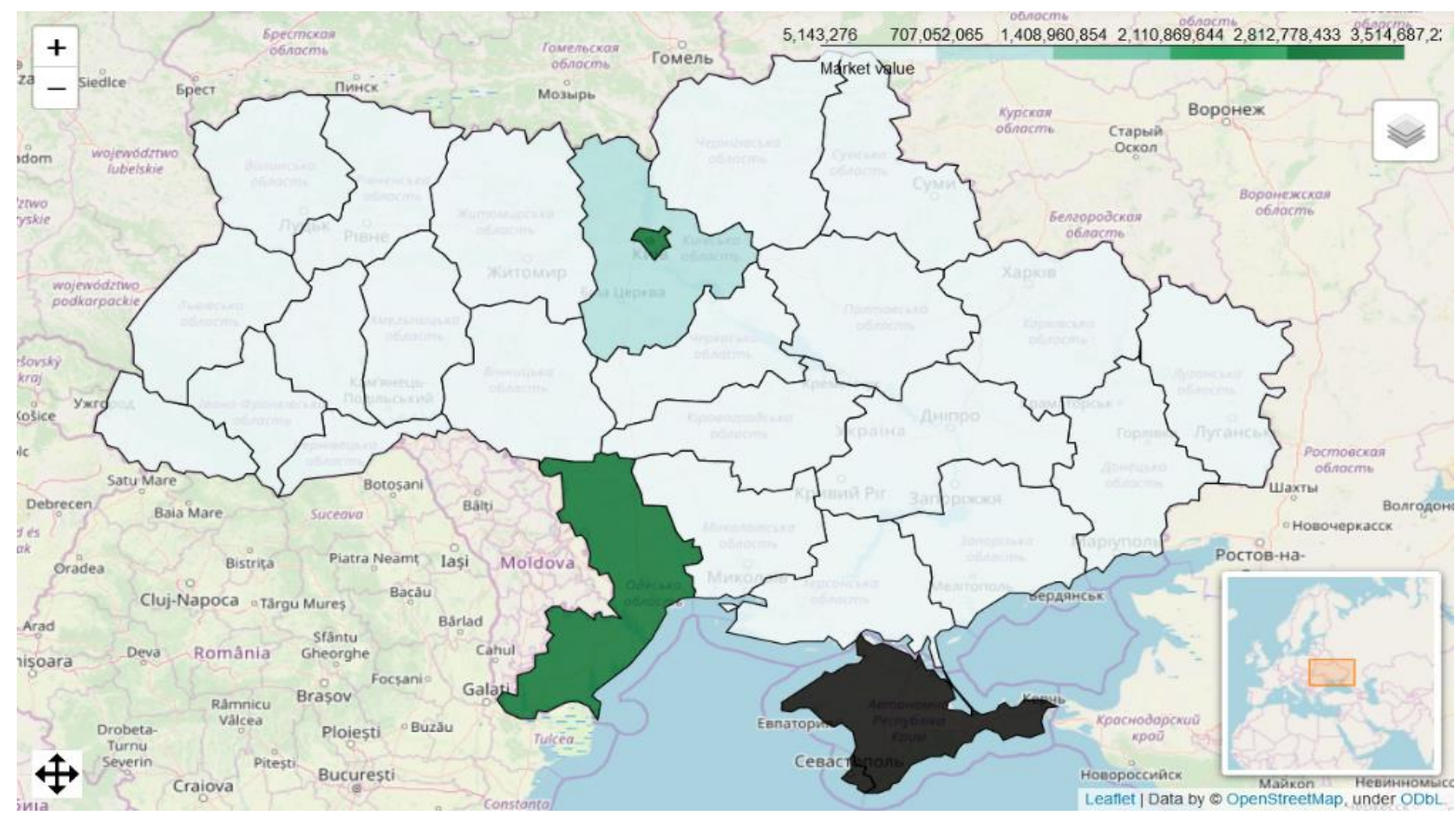

Figure 3. Ukraine's real estate market value according to the region of sale 
Table 4. Ukraine's real estate market value by the region of sale (in US dollars)

\begin{tabular}{|l|l|l|}
\hline Region & Market value & Share \\
\hline Odeska & 3514687222 & 0,320 \\
\hline Kyiv & 3237764652 & 0,295 \\
\hline Kyivska & 849892140 & 0,077 \\
\hline Vinnytska & 525050631 & 0,048 \\
\hline Kharkivska & 411549088 & 0,037 \\
\hline Dnipropetrovska & 346582824 & 0,032 \\
\hline Ternopilska & 283081737 & 0,026 \\
\hline Lvivska & 238389625 & 0,022 \\
\hline Ivano-Frankivska & 197759496 & 0,018 \\
\hline Khersonska & 184199466 & 0,017 \\
\hline Khmelnytska & 168931559 & 0,015 \\
\hline Zaporizka & 159758391 & 0,015 \\
\hline Zakarpatska & 158961998 & 0,014 \\
\hline Mykolaivska & 155573201 & 0,014 \\
\hline Rivnenska & 114585308 & 0,010 \\
\hline Zhytomyrska & 105198504 & 0,010 \\
\hline Poltavska & 80588291 & 0,007 \\
\hline Chernivetska & 66216818 & 0,006 \\
\hline Donetska & 50946614 & 0,005 \\
\hline Cherkaska & 45812840 & 0,004 \\
\hline Volynska & 32199824 & 0,003 \\
\hline Chernihivska & 29162115 & 0,003 \\
\hline Sumska & 16343166 & 0,001 \\
\hline Kirovohradska & 15130088 & 0,001 \\
\hline Luhanska & 5143276 & 0,000 \\
\hline & &
\end{tabular}

Real estate market value according to property type is represented in Table 5. It is not surprising that apartments occupy such a large share $-68 \%$ of the market capitalization. It is more than 4 times higher than the volume of house market, 20 times higher than all commercial and business property.

Table 5. Ukraine's real estate market value according to the property type

\begin{tabular}{|l|l|l|}
\hline Type & Market value & Share \\
\hline Apartments & 7427087721 & 0,676 \\
\hline House & 1837629678 & 0,167 \\
\hline PSN & 285753690 & 0,026 \\
\hline Office_complex & 202191643 & 0,018 \\
\hline Office & 182266631 & 0,017 \\
\hline Land & 168793809 & 0,015 \\
\hline Commercial_area & 157836481 & 0,014 \\
\hline Business & 131940366 & 0,012 \\
\hline Hotel & 128642819 & 0,012 \\
\hline Industrial & 120153625 & 0,011 \\
\hline Recreational & 119683453 & 0,011 \\
\hline Part_of_house & 73013462 & 0,007 \\
\hline Warehouse & 60646115 & 0,006 \\
\hline Services & 55663273 & 0,005 \\
\hline Country_house & 23737203 & 0,002 \\
\hline Room & 11665724 & 0,001 \\
\hline Garage & 4374183 & 0,000 \\
\hline Parking_space & 2428998 & 0,000 \\
\hline
\end{tabular}


Analyzing the property type real estate by the regions (Table 6) it could be seen that Kiev is the leader not in all spheres.

Table 6. Ukraine's real estate market value by the region of sale and the type of property (in thousands of US dollars)

\begin{tabular}{|c|c|c|c|c|c|c|c|c|c|c|c|c|c|c|c|c|}
\hline & 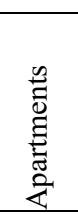 & 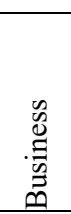 & 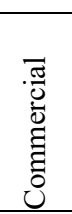 & 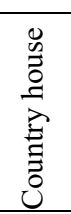 & 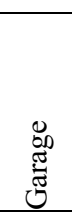 & 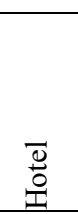 & $\begin{array}{l}\ddot{0} \\
\tilde{O} \\
0 \\
\underline{I}\end{array}$ & 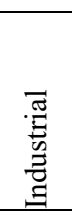 & 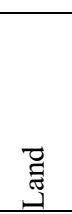 & $\underbrace{0}_{0}$ & 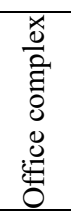 & 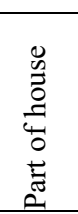 & 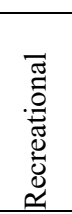 & $\begin{array}{l}\Xi \\
0 \\
\stackrel{0}{0} \\
\underline{1}\end{array}$ & 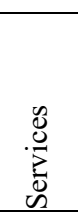 & 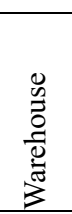 \\
\hline Kyiv & 0,36 & 0,07 & 0,25 & 0,05 & 0,25 & 0,20 & 0,07 & 0,07 & 0,10 & 0,49 & 0,64 & 0,04 & 0,27 & 0,08 & 0,30 & 0,04 \\
\hline Vinnytska & 0,03 & 0,07 & 0,04 & 0,09 & 0,07 & 0,03 & 0,09 & 0,07 & 0,16 & 0,02 & 0,01 & 0,14 & 0,04 & 0,19 & 0,04 & 0,17 \\
\hline Odeska & 0,35 & 0,51 & 0,07 & 0,23 & 0,03 & 0,46 & 0,30 & 0,04 & 0,17 & 0,11 & 0,23 & 0,07 & 0,09 & 0,31 & 0,36 & 0,32 \\
\hline Zak-ska & 0,01 & 0,03 & 0,04 & 0,02 & 0,01 & 0,04 & 0,03 & 0,07 & 0,05 & 0,00 & 0,01 & 0,03 & 0,04 & na & 0,02 & 0,02 \\
\hline Kyivska & 0,05 & 0,02 & 0,02 & 0,16 & 0,04 & 0,03 & 0,20 & 0,13 & 0,13 & 0,02 & 0,01 & 0,18 & 0,08 & 0,02 & 0,03 & 0,08 \\
\hline Khar-ska & 0,03 & 0,03 & 0,25 & 0,04 & 0,04 & 0,01 & 0,03 & 0,06 & 0,01 & 0,21 & 0,02 & 0,03 & 0,02 & 0,12 & 0,02 & 0,02 \\
\hline Mykol-ska & 0,01 & 0,02 & 0,02 & 0,02 & 0,01 & 0,01 & 0,02 & 0,04 & 0,01 & 0,01 & 0,01 & 0,02 & 0,03 & 0,03 & 0,01 & 0,01 \\
\hline Dnip-ska & 0,03 & 0,03 & 0,08 & 0,06 & 0,03 & 0,02 & 0,04 & 0,08 & 0,05 & 0,05 & 0,02 & 0,02 & 0,05 & 0,01 & 0,07 & 0,15 \\
\hline $\begin{array}{l}\text { Khmel- } \\
\text { ska }\end{array}$ & 0,01 & 0,02 & 0,03 & 0,02 & 0,08 & 0,01 & 0,02 & 0,02 & 0,03 & 0,01 & 0,00 & 0,01 & 0,02 & 0,01 & 0,01 & 0,02 \\
\hline Zapo-ka & 0,01 & 0,01 & 0,02 & 0,02 & 0,01 & 0,04 & 0,02 & 0,05 & 0,01 & 0,01 & 0,03 & 0,01 & 0,16 & 0,01 & 0,01 & 0,02 \\
\hline Tern-ska & 0,03 & 0,01 & 0,03 & 0,06 & 0,19 & 0,00 & 0,03 & 0,02 & 0,05 & 0,01 & 0,00 & 0,09 & 0,01 & 0,07 & 0,01 & 0,01 \\
\hline Cher-ska & 0,00 & 0,01 & 0,01 & 0,03 & 0,02 & na & 0,01 & 0,02 & 0,01 & 0,00 & 0,00 & 0,02 & 0,01 & 0,01 & 0,01 & 0,01 \\
\hline Lvivska & 0,02 & 0,03 & 0,04 & 0,02 & 0,07 & 0,06 & 0,03 & 0,07 & 0,05 & 0,02 & 0,01 & 0,03 & 0,05 & 0,01 & 0,04 & 0,06 \\
\hline Rivn-ska & 0,01 & 0,03 & 0,02 & 0,02 & 0,02 & na & 0,02 & 0,01 & 0,02 & 0,01 & 0,00 & 0,09 & 0,03 & 0,02 & 0,01 & 0,01 \\
\hline Volynska & 0,00 & 0,01 & 0,00 & 0,00 & 0,00 & 0,00 & 0,01 & 0,04 & 0,01 & 0,00 & 0,01 & 0,01 & 0,00 & 0,00 & 0,01 & 0,00 \\
\hline $\begin{array}{l}\text { Ivano- } \\
\text { Frank-ska }\end{array}$ & 0,02 & 0,02 & 0,04 & 0,01 & 0,09 & 0,06 & 0,01 & 0,01 & 0,04 & 0,01 & 0,00 & 0,03 & 0,02 & 0,00 & 0,01 & 0,02 \\
\hline Zhytska & 0,01 & 0,01 & 0,00 & 0,04 & 0,01 & 0,00 & 0,01 & 0,03 & 0,02 & 0,01 & na & 0,08 & 0,00 & 0,07 & 0,01 & 0,02 \\
\hline Poltavska & 0,01 & 0,00 & 0,00 & 0,04 & 0,01 & 0,01 & 0,01 & 0,03 & 0,03 & 0,00 & na & 0,01 & 0,00 & 0,01 & 0,01 & 0,00 \\
\hline Khers-ska & 0,01 & 0,03 & 0,00 & 0,03 & 0,01 & 0,01 & 0,03 & 0,02 & 0,02 & 0,00 & na & 0,04 & 0,04 & 0,01 & 0,01 & 0,00 \\
\hline Chern-ska & 0,00 & 0,02 & 0,00 & 0,01 & 0,01 & 0,01 & 0,01 & 0,02 & 0,01 & 0,01 & na & 0,03 & 0,01 & 0,00 & 0,02 & 0,01 \\
\hline $\begin{array}{l}\text { Chernih- } \\
\text { ska }\end{array}$ & 0,00 & 0,00 & 0,01 & 0,01 & 0,00 & 0,00 & 0,00 & 0,08 & 0,00 & 0,00 & 0,00 & 0,01 & 0,01 & 0,01 & 0,00 & 0,00 \\
\hline Kirov-ska & 0,00 & 0,00 & 0,00 & 0,00 & 0,00 & na & 0,00 & 0,00 & 0,00 & 0,02 & na & 0,01 & 0,00 & na & 0,00 & 0,00 \\
\hline Donetska & 0,00 & 0,01 & 0,00 & 0,00 & 0,01 & na & 0,01 & 0,00 & 0,00 & 0,00 & na & 0,00 & 0,00 & 0,00 & 0,00 & 0,00 \\
\hline Sumska & 0,00 & 0,01 & 0,01 & 0,00 & 0,00 & na & 0,00 & 0,00 & 0,00 & 0,00 & na & 0,00 & 0,01 & 0,00 & 0,01 & 0,01 \\
\hline Luhanska & 0,00 & 0,00 & 0,00 & 0,00 & 0,00 & na & 0,00 & 0,00 & 0,00 & 0,00 & 0,01 & 0,00 & 0,00 & na & 0,00 & 0,00 \\
\hline
\end{tabular}

Specifically, for business property, country houses, houses, land, industrial property, part of house, rooms and warehouses. At the same time, Kiev is peremptory leader in the sphere of office and office complex (49 and 64\%), parking (43\%), recreation $(0,27 \%)$. The leaders of apartments are Kiev and Odesa regions (36 and 35\%), other regions significantly lag from Kiev and Odesa. For business property the leader is Odesa (51\%). For commercial property besides Kiev on the top is Kharkiv region (25\%). On the market of country houses the leaders are Odesa region (23\%), Kharkiv region (16\%), Vinnytsia (9\%). Hotel property are market assets for the most at Odesa (46\%) and Kiev (20\%), business - at Kiev (13\%), Dnipropetrovsk (8\%). The 
leaders on warehouse market are Odesa (22\%), Vinnytsia (17\%), Dnipropetrovsk (15\%), Kyiv (8\%).

Conclusions. The investigation described in this paper indicates that using Web scraping for real estate market can be useful for estimation of market capitalization and its structure. The main focus in the paper is limited only to one data source and city, though it could be expanded to other sources, e. g. olx.ua. The evaluation shows the market concentration mostly in Kiev, except for business property, country houses, hotel property, land and warehouses.

\section{References}

1. João Manuel Azevedo Santos. Real Estate Market Data Scraping and Analysis for Financial Investments. URL: https://sigarra.up.pt/reitoria/en/pub_geral.pub_view?pi_pub_base_id=296684 .

2. Maciej Beresewicz. On representativeness of Internet data sources for real estate market in Poland. URL: https://www.researchgate.net/publication/276509483_On_Representativeness_of_Internet_Data_Sources _for_Real_Estate_Market_in_Poland.

3. EzgiCandas, Seda BagdatliKalkan and Tahsin Yomralioglu. Determining the Factors Affecting Housing Prices. URL: https.://www.google.com/url?sa=t\&rct=j\&q=\&esrc=s\&source=web\&cd=1\&cad=rja\&uact= 8\&ved=2ahUKEwiY0I7cyK3oAhVcw8QBHZa3BTsQFjAAegQIBhAB\&url=https\%3A\%2F\%2Fwww.fi g.net\%2Fresources\%2Fproceedings\%2Ffig_proceedings\%2Ffig2015\%2Fpapers\%2Fts08j\%2FTS08J_can das_bagdatli_kalkan_et_al_7868.pdf\&usg=AOvVaw3Z7144oQrHBM7hpaEifz0S.

4. Robert $\mathrm{Hu}$ and Emil Sjogren. Analysis and prediction of apartment prices in inner city Stockholm. URL: $\quad$ https://www.google.com/url?sa=t\&rct=j\&q=\&esrc=s\&source=web\&cd=1\&ved=2ahUKEwic0_ yRyq3o AhWMxosKHc2vCAMQFjAAegQIBRAB\&url=http\%3A\%2F\%2Fwww.divaportal.se\%2Fsmash \%2Fget\%2 Fdiva2\%3A736615\%2FFULLTEXT01.pdf\&usg=AOvVaw1QRz9jDQWeD7ES-p5AFxPu.

5. Mitchell R., Web scraping with Python. O'Reilly Media, 2018, 2 edition. 308 p.

6. Chapagain A., Hands-On Web Scraping with Python: Perform advanced scraping operations using various Python libraries and tools such as Selenium, Regex, and others. Packt Publishing, 2019. 350 p.

7. Park A., Python for Data Analysis: A Step-By-Step Guide to Master the Basics of Data Analysis in Python Using Pandas, Numpy And Ipython. Data Science Book 2. Independently published, 2019. $151 \mathrm{p}$.

8. Petrou T., Pandas Cookbook: Recipes for Scientific Computing, Time Series Analysis and Data Visualization using Python, Packt Publishing, 2017. 1 edition. 534 p.

9. Molin S., Hands-On Data Analysis with Pandas: Efficiently perform data collection, wrangling, analysis, and visualization using Python, Packt Publishing, 2019. 1 edition. 716 p.

10. Kouzis-Loukas D. Learning Scrapy. Packt Publishing, 2016. 415 p.

11. Nelli F., Python Data Analytics. Apress Media, 2018. 576 p. https://doi.org/10.1007/978-1-4842-3913-1

12.E. Beal A. Strategic Market Research: A Guide to Conducting Research that Drives Businesses, Second Edition iUniverse Star, 2010). 96 p.

13. Hauge P., Hauge N., Morgan C., Market Research in Practice: How to Get Greater Insight From Your Market, Kogan Page; Second edition. 2013. 272 p.

14. Pinson L. Anatomy of a Business Plan: The Step-by-Step Guide to Building a Business and Securing Your Company's Future, Out Of Your Mind. And Into The Mark. 7th edition. 2008. 352 p.

15. Frisch B., Creating Business Plans (HBR 20-Minute Manager Series), Harvard Business Review Press, 2014. $162 \mathrm{p}$.

\section{Список використаної літератури}

1. João Manuel Azevedo Santos. Real Estate Market Data Scraping and Analysis for Financial Investments. URL: https://sigarra.up.pt/reitoria/en/pub_geral.pub_view?pi_pub_base_id=296684 .

2. Maciej Beresewicz. On representativeness of Internet data sources for real estate market in Poland. URL: https://www.researchgate.net/publication/276509483_On_Representativeness_of_Internet_Data_Sources _for_Real_Estate_Market_in_Poland.

3. EzgiCandas, Seda BagdatliKalkan and Tahsin Yomralioglu. Determining the Factors Affecting Housing Prices. URL: https.://www.google.com/url?sa=t\&rct=j\&q=\&esrc=s\&source=web\&cd=1\&cad=rja\&uact= 
8\&ved=2ahUKEwiY0I7cyK3oAhVcw8QBHZa3BTsQFjAAegQIBhAB\&url=https\%3A\%2F\%2Fwww.fi g.net\%2Fresources\%2Fproceedings\%2Ffig_proceedings\%2Ffig2015\%2Fpapers\%2Fts08j\%2FTS08J_can das_bagdatli_kalkan_et_al_7868.pdf\&usg=AOvVaw3Z7144oQrHBM7hpaEifz0S.

4. Robert $\mathrm{Hu}$ and Emil Sjogren. Analysis and prediction of apartment prices in inner city Stockholm. URL: $\quad$ https://www.google.com/url?sa=t\&rct=j\&q=\&esrc=s\&source=web\&cd=1\&ved=2ahUKEwic0_ yRyq3o AhWMxosKHc2vCAMQFjAAegQIBRAB\&url=http\%3A\%2F\%2Fwww.divaportal.se\%2Fsmash $\% 2$ Fget\%2 Fdiva2\%3A736615\%2FFULLTEXT01.pdf\&usg=AOvVaw1QRz9jDQWeD7ES-p5AFxPu.

5. Mitchell R., Web scraping with Python. O'Reilly Media, 2018, 2 edition. 308 p.

6. Chapagain A., Hands-On Web Scraping with Python: Perform advanced scraping operations using various Python libraries and tools such as Selenium, Regex, and others. Packt Publishing, 2019. 350 p.

7. Park A., Python for Data Analysis: A Step-By-Step Guide to Master the Basics of Data Analysis in Python Using Pandas, Numpy And Ipython. Data Science Book 2. Independently published, 2019. 151 p.

8. Petrou T., Pandas Cookbook: Recipes for Scientific Computing, Time Series Analysis and Data Visualization using Python, Packt Publishing, 2017. 1 edition. 534 p.

9. Molin S., Hands-On Data Analysis with Pandas: Efficiently perform data collection, wrangling, analysis, and visualization using Python, Packt Publishing, 2019. 1 edition. 716 p.

10. Kouzis-Loukas D. Learning Scrapy. Packt Publishing, 2016. 415 p.

11. Nelli F., Python Data Analytics. Apress Media, 2018. 576 p. https://doi.org/10.1007/978-1-4842-3913-1

12. E. Beal A. Strategic Market Research: A Guide to Conducting Research that Drives Businesses, Second Edition iUniverse Star, 2010). 96 p.

13. Hauge P., Hauge N., Morgan C., Market Research in Practice: How to Get Greater Insight From Your Market, Kogan Page; Second edition. 2013. 272 p.

14. Pinson L. Anatomy of a Business Plan: The Step-by-Step Guide to Building a Business and Securing Your Company's Future, Out Of Your Mind. And Into The Mark. 7th edition. 2008. 352 p.

15. Frisch B., Creating Business Plans (HBR 20-Minute Manager Series), Harvard Business Review Press, 2014. 162 p. 